Олексій Самойленко

Навчально-науковий інститут інформаційної безпеки Служби Безпеки України ORCID ID 0000-0002-6374-4168

DOI 10.24139/2312-5993/2020.05-06/137-149

\title{
МЕТОДИЧНІ АСПЕКТИ ФОРМУВАННЯ ГОТОВНОСТІ БАКАЛАВРІВ 3 КІБЕРБЕЗПЕКИ ДО ПРОФЕСІЙНОЇ ДІЯЛЬНОСТІ ЗАСОБАМИ КОЛАБОРАТИВНОГО НАВЧАННЯ В УМОВАХ ОСВІТНЬО-ЦИФРОВОГО СЕРЕДОВИЩА
}

у статті окреслено методичні аспекти формування готовності бакалаврів $з$ кібербезпеки до професійної діяльності засобами колаборативного навчання в умовах освітньо-цифрового середовища, здатні підвищити рівень їх фахової підготовки. Окреслено готовність бакалавра з кібербезпеки до професійної діяльності, яка по суті являє собою вибіркову та прогнозовану активність особистості бакалавра з кібербезпеки на етапі ї̈ підготовки до діяльності за фахом та виникає з моменту визначення мети діяльності на основі усвідомлених потреб і мотивів, а в подальшому розвивається внаслідок вироблення особистістю плану, настанов і моделей майбутніх дій. Доведено, що готовність бакалавра з кібербезпеки до професійної діяльності можна формувати засобами колаборативного навчання в умовах освітньо-цидрового середовища. Визначено структуру віртуального моделювання в онлайн-лабораторії для бакалаврів з кібербезпеки в умовах освітньо-цифрового середовища, яка складається з трьох інтерфейсів: інтерфейс здобувача вищої освіти, інтерфейс викладача та інтерфейс адміністратора. Зазначено, що важливим під час колаборативного навчання бакалаврів з кібербезпеки $\epsilon$ те, що середовище, у якому відбувається їх взаємодія, повинна будуватися на демократії, рівноправності та автономності, з таким правилом навчання буде відбуватися на високому рівні і в результаті пройде успішно.

Ключові слова: колаборативне навчання, готовність до професійної діяльності, бакалавр з кібербезпеки, освітньо-цифрове середовище.

Постановка проблеми. Для мінімізації ризиків у Європі в 2018 році наберуть чинності закони про захист даних. Вони передбачають різке підвищення штрафів за розголошення або втрату персональних даних, що змусить компанії вже в цьому році переглянути свої підходи і стандарти щодо забезпечення інформаційної та кібернетичної безпеки, у тому числі ввести окрему посаду відповідального за захист інформації та кібернетичну безпеку. Важливим фактором посилення заходів кібернетичної безпеки $є$ збереження балансу між комфортом, свободою доступу до інформації й забезпеченням надійного захисту інформації, від яких багато в чому залежить благополуччя громадян і мир в Україні. Однак, це завдання непросте, і його доведеться вирішувати ще довгий час. 
Масштабна кібератака на корпоративні та державні мережі за допомогою вірусу «NotPetya», яка відбулася 27 червня 2017 року, - яскравий приклад важливості кібернетичної безпеки для функціонування держави. Масові відключення електроенергії, телефонного зв'язку та Інтернету, труднощі $з$ обслуговуванням клієнтів і проведенням банківських операцій, фінансові збитки вказують нам на нестачу фахівців належного рівня з кібербезпеки та потребою вдосконалення методик їх сучасної підготовки. Методичні аспекти формування готовності до професійної діяльності засобами колаборативного навчання бакалаврів з кібербезпеки в умовах освітньоцифрового середовища здатні підвищити рівень їх фахової підготовки.

Метою статті: окреслити методичні аспекти формування готовності бакалаврів 3 кібербезпеки до професійної діяльності засобами колаборативного навчання в умовах освітньо-цифрового середовища.

Методи дослідження. Окреслення методичних аспектів формування готовності бакалаврів з кібербезпеки до професійної діяльності підлягало проведенню аналізу та узагальнення історичної, філософської, педагогічної літератури з проблеми підготовки бакалаврів з кібербезпеки засобами колаборативного навчання в умовах освітньо-цифрового середовища. Аналітичне дослідження сучасних педагогічних джерел надало можливість уточнення сутності понятійного апарату дослідження. Пошукові методи дослідження сприяли аналізу досліджуваної проблеми в контексті соціально-економічних та культурно-освітніх змін у суспільстві, визначення сутності, основних ознак, особливостей функціонування, етапів розвитку; узагальнення вітчизняного й зарубіжного досвіду підготовки бакалаврів з кібербезпеки до професійної діяльності в умовах освітньо-цифрового середовища. Отримані результати засвідчили необхідність розробки методичних аспектів формування готовності бакалаврів з кібербезпеки до професійної діяльності засобами колаборативного навчання в умовах освітньо-цифрового середовища.

Виклад основного матеріалу. Результатом професійної підготовки фахівця $\epsilon$ готовність до професійної діяльності. Огляд словникових визначень підводить до висновку про те, що термін «підготовка» збагачує поняття «готовність»: підготовка до професії розглядається як процес формування готовності до неї, а готовність - як результат професійної підготовки. Тому ідеологія термінів «підготовка» i «готовність» взаємопов'язані та взаємозумовлені.

В українських словниках готовність виражає закінченість, кінцевий результат певної дії (Гончаренко, 1997; Кудрицкий, 1989; Кремінь, 2008). 
Проблема готовності в контексті професійного становлення особистості фахівця з кібербезпеки - це одна з найважливіших для загальної і педагогічної психології. Не існує однозначного розуміння сутності й функцій зазначеного поняття, яке набуло останнім часом у концептуальному апараті психології відносно самостійного і високого наукового статусу. Проте відмінності у визначенні поняття готовності, що мають місце в різних авторів, дають підстави говорити про суперечливість існуючих точок зору, а звідси і про неузгодженість процедур перенесення цього поняття в експериментальну площину (Доценко, 2019; Плахотнюк, 2010).

Сутність поняття готовності вимагає переосмислення його змісту й функцій на методологічному та експериментальному рівнях. Дослідження цього напряму базуються на вивченні і психологічному обґрунтуванні засобів навчання й удосконалення системи підготовки спеціалістів (Гуцан, 2018).

Процес переосмислення функції освіти на гуманістичних засадах, що передбачає орієнтацію змісту освіти на актуалізацію можливостей особистості, перетворення останньої на суб'єкт навчальної діяльності, здатної до свідомого професійного самовизначення, саморозвитку, вільного вибору свого життєвого шляху, вимагає певних змін у розбудові загальної стратегії організації навчально-виховного процесу в закладах освіти, у тому числі і в ділянці вирішення проблеми формування в учнівської молоді готовності до професійної праці в тій чи іншій галузі трудової діяльності. Підготовку до професійної діяльності треба розглядати в контексті розвитку особистості. У зв'язку з цим основу формування готовності до професійної діяльності розглядають не тільки як розвиток операційно-технічних умінь та навичок, а й такий визначальний параметр готовності, як комплексна здібність. Комплексна здібність розглядається як утворення, що складається з мотиваційної (схильність до певної діяльності) та інструментальної (інтелектуальні та емоційні механізми регуляції діяльності) сторін (Бондаренко, 2020; Бацуровська, 2015).

Готовність як інтегральне утворення особистості, що полягає у вибірковій спрямованості на педагогічну діяльність, виникає на ґрунті позитивного ставлення і скеровується відповідними потребами та мотивами до даної діяльності. Про сформовану готовність можна говорити лише за умови розвинутості в суб'єкта емоційного ставлення, уміння адаптувати свою поведінку відповідно до ситуацій, що виникають, уміння будувати процес спілкування, сформованості таких педагогічних здібностей, як мислення, уявлення, спостережливість, комунікативних 
умінь і широкого набору професійно значущих властивостей: емоційної стабільності, самоконтролю, щирості, доброти, наполегливості тощо.

У своїх дослідженнях В. А. Сластьонін $(1996$, с. 3) вважає готовність до професійної діяльності однією з базових характеристик особи соціального працівника. Учений підкреслює особливу актуальність завдання формування готовності здобувачів освіти.

Результати різнопланових досліджень сформували й різні точки зору науковців щодо компонентів готовності. Одна з них представлена як готовність, що формується через сукупність мотиваційних, пізнавальних, емоційних і вольових якостей особистості, спрямованості особистості на виконання певних дій; у конкретній ситуації має враховуватися загальний психофізіологічний стан, що забезпечує використання можливостей людини. Розширює поняття готовності В. А. Крутецький (Крутецкий, 1978, с. 45), а саме автор пропонує називати готовністю до діяльності інтеграцію властивостей особистості, що включають і здібності, необхідні для виконання певної діяльності.

Заслуговує на увагу думка М. Д. Левітова, який тлумачить готовність як цілісне виявлення особистості та пропонує розглядати її формування на основі інтеграції психічних станів і властивостей особистості (Левитов, 1964). На думку вченого, психічні стани становлять вагому галузь внутрішнього світу людини і характеризують їі психічну діяльність.

На нашу думку, найоптимальніше розкриття досліджуваної проблеми $€$ розуміння готовності як самостійного психічного явища, представленого М.ІІ. Д’яченко та Л. А. Кандибовичем (1976, с. 38). Ученні визначають готовність як вибіркову та прогнозовану активність особистості на етапі їі підготовки до певної діяльності й наголошують, що цей стан виникає з моменту визначення людиною мети діяльності на основі усвідомлених потреб і мотивів. У подальшому готовність розвивається внаслідок вироблення особистістю плану, настанов і моделей майбутніх дій. Готовність у завершальній стадії реалізується у предметних діях, які відповідають чітко визначеним засобам і способам діяльності. Науковці зазначають, що стан психологічної готовності має складну динамічну структуру, виражає сукупність інтелектуальних, емоційно-вольових і мотиваційних складових психіки людини в їхньому співвідношенні 3 умовами, що виникли, і майбутніми завданнями.

Щодо готовності бакалавра $з$ кібербезпеки до професійної діяльності, можна розуміти по суті вибіркову та прогнозовану активність особистості бакалавра з кібербезпеки на етапі ії підготовки до діяльності за 
фахом та виникає з моменту визначення мети діяльності на основі усвідомлених потреб і мотивів, а в подальшому розвивається внаслідок вироблення особистістю плану, настанов і моделей майбутніх дій.

щодо готовності бакалавра з кібербезпеки до професійної діяльності можна формувати засобами колаборативного навчання в умовах освітньоцифрового середовища. Важливим під час колаборативного навчання бакалаврів з кібербезпеки $\epsilon$ те, що середовище, у якому відбувається їх взаємодія повинна будуватися на демократії, рівноправності та автономності. Тільки з таким правилом навчання буде відбуватися на високому рівні і в результаті пройде успішно. В основі застосування колаборативних освітніх платформ покладено консенсус, що формується на основі кооперації бакалаврів з кібербезпеки на противагу змагальному принципу, що $\epsilon$ характерним для традиційної педагогіки. Це рекурсивний процес, коли бакалаври з кібербезпеки з бажанням і прагненням налаштовані на співпрацю. Зауважимо, що учасники колаборативної групи мають характерні ознаки комунікативності та ініціативності, вони всі повинні прагнути налаштовуватися на співпрацю й вибудовувати таку стратегію розв'язку поставленої задачі, аби разом досягти результату (Самойленко, 2019).

Колаборативні освітні платформи для бакалаврів з кібербезпеки мають включати такі формати, як групові проекти, спільні розробки тощо.

Колаборативне навчання в мобільних додатках. Організація колаборативного навчання бакалаврів з кібербезпеки в умовах освітньо-цифрового середовища має бути побудована на принципах соціального контакту.

До основних принципів застосування колаборативного навчання в мобільних додатках для бакалаврів з кібербезпеки в умовах освітньоцифрового середовища можна віднести такі:

- систематичне встановлення соціальних контактів під час підготовки бакалаврів з кібербезпеки,

- розвиток комунікабельності в бакалаврів з кібербезпеки;

- взаємини між бакалаврами з кібербезпеки в умовах освітньоцифрового середовища мають будуватися на демократичності та автономії;

- ролі учасників освітнього процесу можуть змінюватися в часовому просторі в залежності від сутності та природи проблемного завдання;

- психологічна комфортність (Рис. 1).

Під час створення комп'ютерних тестів у мобільних додатках для бакалаврів з кібербезпеки в умовах освітньо-цифрового середовища слід ураховувати відповідну шкалу оцінювання. Так, кожна колаборативна група має можливість розробляти тести за певною шкалою оцінювання (5- 
ти, 10-ти, 12-ти бальними шкалами тощо). Також бакалаври з кібербезпеки можуть об'єднуватися в малі групи згідно з типами завдань тесту, їх різновидами, темами, певними програмами, видами завдань, за формами адаптивного тестового контроля в умовах освітньо-цифрового середовища тощо. Такий підхід підвищує відповідальність учасників колаборативної групи за виконане завдання.

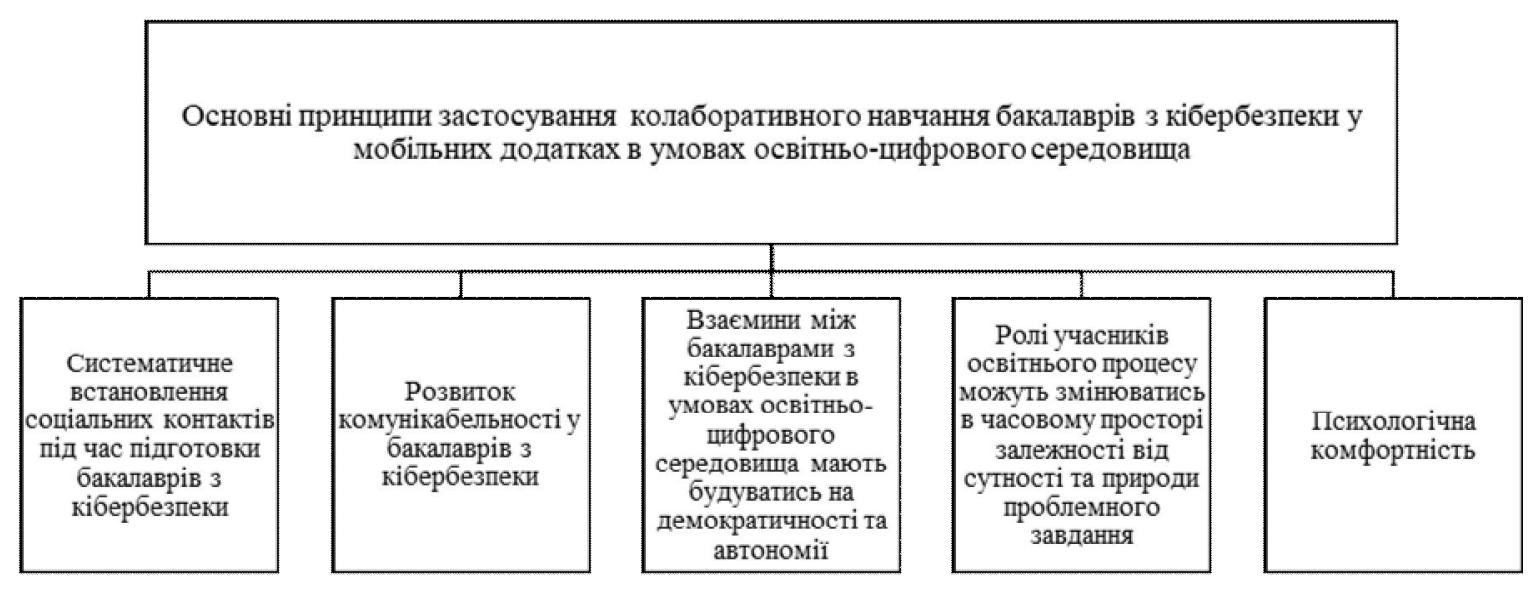

Рис. 1. Основні принципи застосування колаборативного навчання бакалаврів з кібербезпеки в умовах освітньо-цифрового середовища

Розробка технології колаборативного навчання в мобільних додатках комп'ютерних тестів надає потужний функціонал для реалізації освітнього процесу та має значні дидактичні можливості. У результаті організації такого навчання в бакалаврів з кібербезпеки формуються позитивні самоосвітні мотиви, уміння цілепокладання, планування, рефлексії, самоконтролю, комунікативні здібності, здатність до ефективної взаємодії з іншими людьми.

Колаборативні онлайн-платформи. Під час організації навчання в колаборативних онлайн-платформах дуже добре реалізується проектна цифрова діяльність, коли перед колективом ставиться завдання створення єдиного проекту, але для цього його необхідно розбити на підзадачи, кожна з яких вирішується індивідуально або групою учасників. Проєктний характер роботи бакалаврів 3 кібербезпеки, співпраця, формування єдиного продукту спільної діяльності наповнюють змістом роботу в умовах освітньо-цифрового середовища, забезпечуючи тим самим змістову взаємодію, обмін знаннями, оцінку й постійне вдосконалення робіт (Самойленко, 2019). 
Освітня діяльність в умовах освітньо-цифрового середовища за допомогою інструментів соціальних сервісів формує в бакалаврів 3 кібербезпеки такі вміння, як організація своєї діяльності, тобто визначення іiі цілей і завдань, вибір засобів для реалізації цих цілей і застосування їх на практиці, взаємодія з іншими учасниками освітнього процесу, оцінка досягнутих результатів, у результаті відбувається формування навчальнопізнавальних та цифрових компетенцій.

Віртуальні моделі і онлайн-лабораторії. Освітні віртуальні моделі і онлайн-лабораторії в умовах освітньо-цифрового середовища дозволяють бакалаврам з кібербезпеки проводити віртуальні експерименти як у тривимірному просторі, так і в двомірному. Віртуальні моделі в онлайнлабораторії дозволяють представити складні процеси, які відбуваються всередині механізмів та кіберсистем (Самойленко, 2019).

Ефективне застосування віртуальні моделей і онлайн-лабораторій в освітньому процесі сприяє не тільки підвищенню якості підготовки бакалаврів з кібербезпеки, а й економії фінансових ресурсів, які створюють безпечне, екологічне чисте середовище (Рис. ) (Самойленко, 2019).
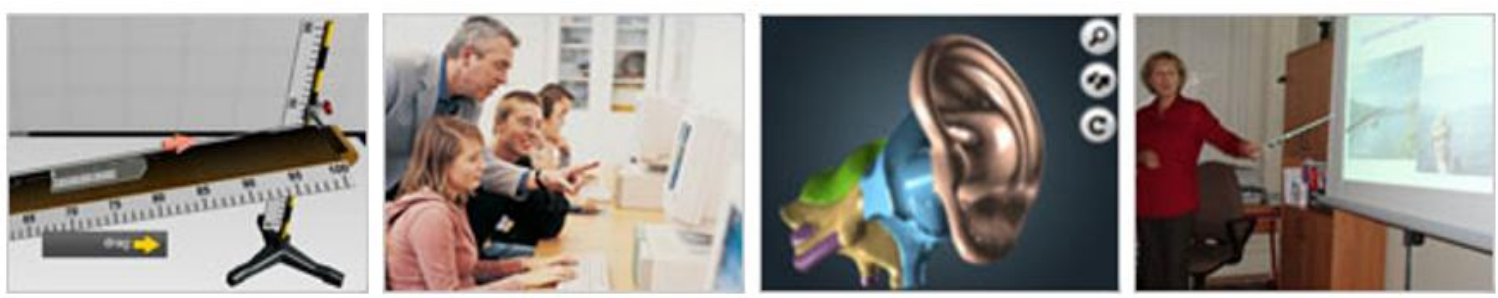

Рис. 2. Фрагменти застосування віртуальних моделей і онлайнлабораторій

Віртуальні лабораторні роботи можна демонструвати під час лекції як доповнення до лекційних матеріалів. Змінюючи параметри в інтерактивній лабораторії, користувач бачить зміни в 3D-середовищі як результат своїх дій.

Використання в навчальному процесі віртуальних лабораторій в умовах освітньо-цифрового середовища дозволяє забезпечити:

- індивідуальне навчання бакалаврів з кібербезпеки без перерв;

- можливість модульного поділу лабораторної роботи в умовах освітньо-цифрового середовища;

- можливість паралельного використання на лекційних, практичних і лабораторних заняттях в процесі підготовки бакалаврів з кібербезпеки;

- поетапне вивчення технологічних процесів;

- можливість аналізу експериментальних даних одночасно 3 експериментом; 
- можливість модифікації і вдосконалення, внесення коректив до існуючої моделі.

Використання віртуальних лабораторій у навчальному процесі закладу вищої технічної освіти дає змогу, з одного боку, отримати практичні навички проведення експериментів, ознайомитися детально з комп'ютерною моделлю сучасного обладнання, досліджувати пожежо- i вибухонебезпечні процеси і явища, не побоюючись за можливі наслідки. 3 іншого боку, $€$ можливість організувати взаємодію віртуального лабораторного комплексу із реально діючим обладнанням підприємств для збору експериментальних даних, що забезпечить відповідний рівень розвитку наукових розробок і технологічного керування процесом 3 кібербезпеки (Самойленко, 2019).

Структура віртуального моделювання в онлайн-лабораторії (Рис. ) для бакалаврів з кібербезпеки в умовах освітньо-цифрового середовища складається з трьох інтерфейсів: інтерфейс здобувача вищої освіти, інтерфейс викладача та інтерфейс адміністратора.

Інтерфейс здобувача вищої освіти включає такі компоненти:

- блок допуску бакалаврів з кібербезпеки до виконання віртуальної лабораторної роботи (тест);

- пояснення та візуалізація технологічної моделі в умовах освітньоцифрового середовища;

- виконання й обробка результатів дослідів в умовах освітньоцифрового середовища;

- інтерфейс контролю знань бакалаврів з кібербезпеки.

Інтерфейс викладача закладає в основу:

- формування теоретичного матеріалу та завдань для бакалаврів 3 кібербезпеки;

- формування допускного та контрольного тестування в умовах освітньо-цифрового середовища;

- формування результатів тестування та їх аналіз в умовах освітньоцифрового середовища;

- інтерфейс аналізу результатів роботи бакалаврів з кібербезпеки.

Інтерфейс адміністратора включає:

- базу даних навчальних фрагментів освітнього процесу бакалаврів 3 кібербезпеки;

- базу даних параметрів для моделювання в освітньо-цифровому середовищі; 
- базу результатів контролю знань й виконання завдань бакалаврами з кібербезпеки;

- базу результатів виконання досліджень в освітньо-цифровому середовищі.

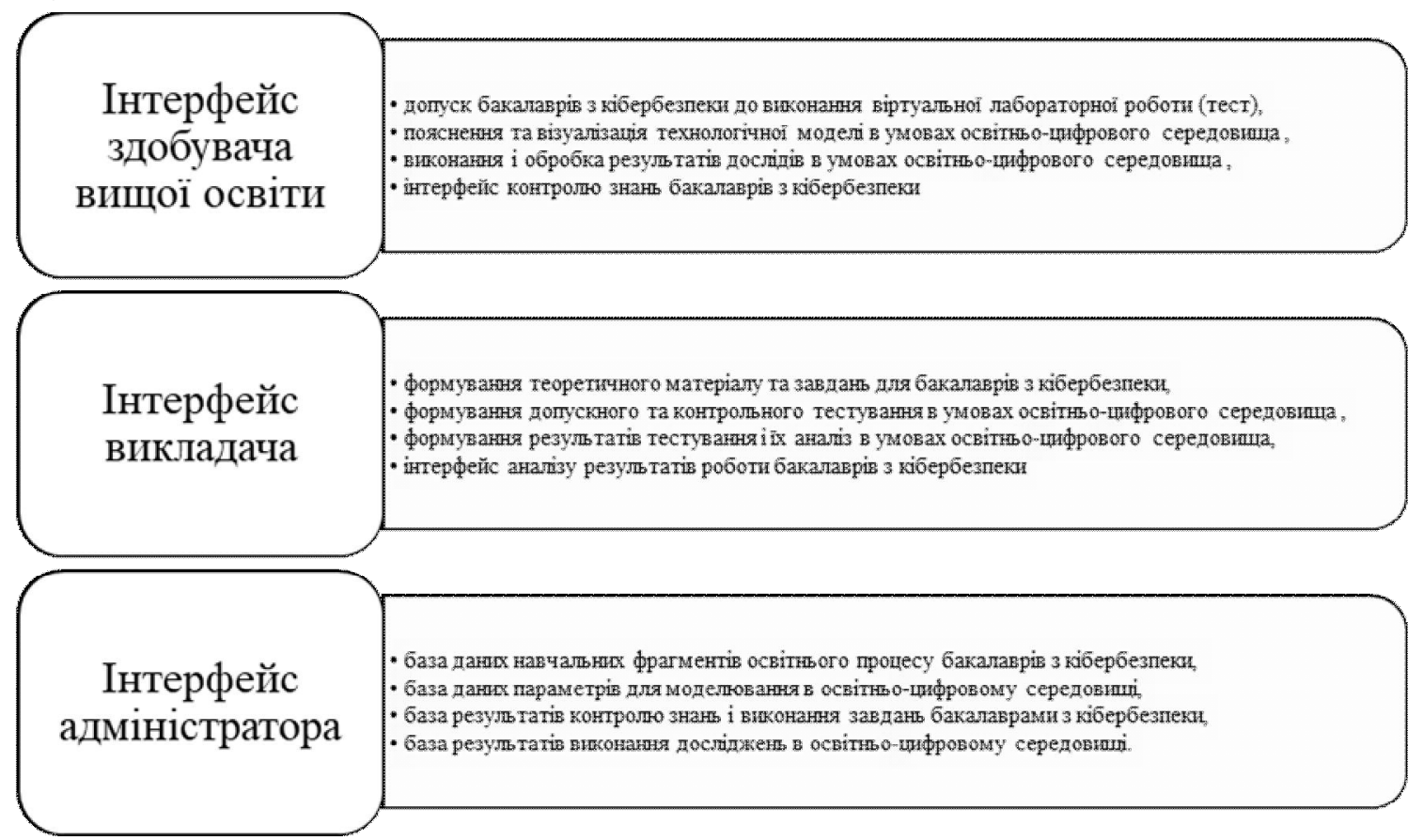

Рис. 3. Структура віртуального моделювання в онлайн-лабораторії для бакалаврів з кібербезпеки в умовах освітньо-цифрового середовища

Виконання лабораторних робіт у віртуальній навчальній лабораторії відбувається з урахуванням правил роботи з технологічним обладнанням і правил техніки безпеки, що дає можливість засвоєння додаткових знань про виробництво. Для створення моделі функціонування обладнання використовуються показники роботи реального обладнання. Для закріплення знань із дисципліни передбачено: тестові завдання, навчальний матеріал, основна література й додаткові літературні джерела.

Для початку роботи з віртуальною моделлю в онлайн-лабораторії бакалаврам з кібербезпеки необхідно отримати доступ, виконавши тестові завдання. Якщо бакалавр з кібербезпеки не отримав доступ, тобто не склав позитивно тест, тоді йому надається теоретичний контент, що містить навчальний матеріал. Після отримання допуску можна перейти до виконання завдань.

Після отримання допуску в умовах освітньо-цифрового середовища безпосередньо розпочинається робота з віртуальним стендом. Під час налаштування стенду встановлюються початкові параметри роботи обладнання, на основі яких буде проведено дослід. Кожний наступний дослід потребує переналаштування стенду бакалаврами з кібербезпеки. 
Результати проведених дослідів фіксуються в таблиці результатів в освітньо-цифровому середовищі. Тут же $\epsilon$ можливість опрацювати отримані результати і проаналізувати значення, отримані дослідним шляхом, записати висновки про роботу у відповідне вікно сторінки. У залежності від конкретної лабораторної роботи - це можуть бути висновки, що містять абсолютні чи відносні похибки роботи лабораторного обладнання, а також словесне формулювання. За потреби, бакалаври 3 кібербезпеки можуть попрацювати на сторінці 3 рекомендованою літературою (Самойленко, 2019).

Висновки та перспективи подальших досліджень. Таким чином, окреслити методичні аспекти формування готовності бакалаврів 3 кібербезпеки до професійної діяльності засобами колаборативного навчання в умовах освітньо-цифрового середовища здатні підвищити рівень їх фахової підготовки. Щодо готовності бакалавра з кібербезпеки до професійної діяльності, її можна розуміти як вибіркову та прогнозовану активність особистості бакалавра з кібербезпеки на етапі ії̈ підготовки до діяльності за фахом, що виникає з моменту визначення мети діяльності на основі усвідомлених потреб і мотивів, а в подальшому розвивається внаслідок вироблення особистістю плану, настанов і моделей майбутніх дій. Щодо готовності бакалавра з кібербезпеки до професійної діяльності можна формувати засобами колаборативного навчання в умовах освітньоцифрового середовища. Важливим під час колаборативного навчання бакалаврів з кібербезпеки $€$ те, що середовище, у якому відбувається їх взаємодія, повинна будуватися на демократії, рівноправності та автономності. Тільки з таким правилом навчання буде відбуватися на високому рівні і в результаті пройде успішно.

\section{ЛІТЕРАТУРА}

Бацуровська, І. В. (2015). Сутність показників, критеріїв та рівнів готовності магістрів до освітньо-наукової діяльності в умовах масових відкритих дистанційних курсів. Збірник наукових праць Херсонського начіонального технічного університету, 2, 11-15 (Batsurovska, I. V. (2015). The essence of indicators, criteria and levels of readiness of masters for educational and scientific activities in the conditions of mass open distance courses. Collection of scientific works of Kherson National Technical University, 2, 11-15).

Бондаренко, Р. М. (2020). Професійна готовність майбутнього психолога до роботи 3 дітьми аутичного спектру. Вісник, сс. 272-277 (Bondarenko, R. М. (2020). Professional readiness of the future psychologist to work with children with autism spectrum. Bulletin, ss. 272-277).

Гончаренко, С. У. (1997). Український педагогічний словник. Київ: Либідь (Honcharenko, S. U. (1997). Ukrainian pedagogical dictionary. Kyiv: Lybid). 
Гуцан, Т. Г. (2018). Педагогічні умови формування готовності майбутніх вчителів економіки до профільного навчання старшокласників. Отримано з: http://intkonf.org/gutsan-tg-pedagogichni-umovi-formuvannya-gotovnosti-

maybutnih-vchiteliv-ekonomiki-do-profilnogo-navchannya-starshoklasnikiv/ (Hutsan, T. H. (2018). Pedagogical conditions for the formation of readiness of future teachers of economics for specialized training of high school students. Retrieved from: http://intkonf.org/gutsan-tg-pedagogichni-umovi-formuvannya-gotovnostimaybutnih-vchiteliv-ekonomiki-do-profilnogo-navchannya-starshoklasnikiv/).

Доценко, Н. А. (2019). Дослідження критеріїв готовності майбутніх агроінженерів до професійної діяльності. Теорія прийняття рішень, (сс. 219-220). Ужгород (Dotsenko, N. A. (2019). Research of criteria of readiness of future agroengineers for professional activity. Decision Theory, (pp. 219-220). Uzhhorod).

Дьяченко, М. И., Кандыбович, Л. А. (1976). Психологические проблемы готовности к деятельности. Мн.: БГУ (Diachenko, M. I., Kandybovich, L. A. (1976). Psychological problems of readiness for activity. $\mathrm{M}$ insk: BSU).

Кремінь, В. Г. (2008). Енциклопедія освіти. К.: Юрінком Інтер (Kremin, V. Н. (2008). Encyclopedia of Education. K.: Jurinkom Inter).

Крутецкий, В. А. (1978). Исследование структуры и условий развития способностей. М.: Просвита (Krutetsky, V. А. (1978). Study of the structure and conditions for the development of abilities. M .: Prosvita).

Кудрицкий, А. В. (Ред.) (1989). Украинский Советский энциклопедический словарь (Т. III). Київ: Глав.ред. УСэ (Kudritsky, А. V. (Ed.) (1989). Ukrainian Soviet Encyclopedic Dictionary (T. III). Kyiv: Chief ed. SSE).

Левитов, Н. Д. (1964 ). О психологических состояниях человека. M. (Levitov, N. D. (1964). On the psychological states of a person. M.).

Плахотнюк, Н. П. (2010). Критерії та показники рівня готовності майбутніх учителів до інноваційної діяльності. Вісник Слов'янського державного педагогічного університету, Ч. II (5), 181-191 (Plakhotniuk, N. P. (2010). Criteria and indicators of the level of readiness of future teachers for innovation. Bulletin of the Slavic State Pedagogical University, Part II (5), 181-191).

Самойленко, О. О. (2019). Підготовка бакалаврів з кібербезпеки в умовах освітньоцифрового середовища (Samoilenko, О. О. (2019). Training of bachelors in cybersecurity in an educational and digital environment).

Сластенин, В. А. (1996). Университетское педагогическое образование: проблемы и решения. Профресионально-педагогическая культура: история, теория, технология: материалы Всесоюзной науч.-практ. конф. 9-11 октября, (сс. 3-7). Белград: БГу (Slastenin, V. А. (1996). University pedagogical education: problems and solutions. Professional and pedagogical culture: history, theory, technology: materials of the All-Union scientific-practical. conf. October 9-11, (pp. 3-7). Belgrade: BSU).

\section{PEЗЮME}

Самойленко Александр. Методические аспекты формирования готовности бакалавров по кибербезопасности к профессиональной деятельности средствами колаборативного обучения в условиях образовательно-цифровой среды.

В статье обозначены методические аспекты формирования готовности бакалавров по кибербезопасности к профессиональной деятельности средствами 
колаборативного обучения в условиях образовательно-цифровой среды и способны повысить уровень их профессиональной подготовки. Определена готовность бакалавра по кибербезопасности к профессиональной деятельности, которая по сути представляет собой выборочную и прогнозируемую активность личности бакалавра по кибербезопасности на этапе его подготовки к деятельности по специальности и которая возникает с момента определения цели деятельности на основе осознанных потребностей и мотивов, а в дальнейшем развивается вследствие выработки личностью плана, установок и моделей будущих действий. Доказано, что готовность бакалавра по кибербезопасности в профессиональной деятельности можно формировать средствами колаборативних обучения в условиях образовательноцифровой среды. Определена структура виртуального моделирования в онлайнлаборатории для бакалавров по кибербезопасности в условиях образовательноцифровой среды, которая состоит из трех интерфейсов: интерфейс соискателя высшего образования, интерфейс преподавателя и интерфейс администратора. Отмечено, что важным при колаборативном обучении бакалавров по кибербезопасности является то, что среда, в которой происходит их взаимодействие, должна строиться на демократии, равноправии и автономии, с таким правилом обучения будет происходить на высоком уровне и в результате пройдет успешно.

Ключевые слова: колаборативное обучение, готовность к профессиональной деятельности, бакалавр по кибербезопасности, образовательно-цифровая среда.

\section{SUM M ARY}

Samoilenko Oleksii. Methodological aspects of forming cybersecurity bachelors' readiness for professional activity by means of collaborative training in the conditions of educational and digital environment.

The article outlines the methodological aspects of forming the readiness of bachelors in cybersecurity for professional activities by means of collaborative learning in an educational and digital environment that can increase the level of their professional training. The readiness of a bachelor in cybersecurity for professional activity is outlined, which in essence is a selective and predictable activity of a bachelor in cybersecurity at the stage of its preparation for professional activity and arises from the moment of determining the purpose of activity on the basis of perceived needs and motives, personality plan, guidelines and models for future action. It is proved that the readiness of a bachelor in cybersecurity for professional activity can be formed by means of collaborative learning in an educational and digital environment. That is, the readiness of the bachelor of cybersecurity for professional activities, we can understand essentially selective and predictable activity of the bachelor of cybersecurity in the preparation for the profession and arises from the moment of determining the purpose of activities based on perceived needs and motives, personality plan, guidelines and models for future action. The structure of virtual modeling in the online laboratory for bachelors in cybersecurity in the educational-digital environment is determined, which consists of three interfaces: the interface of the higher education applicant, the interface of the teacher and the interface of the administrator. It is noted that it is important in the collaborative training of bachelors in cybersecurity that the environment in which they interact should be based on democracy, equality and autonomy, with this rule training will be at a high level and as a result will be successful. The organization of collaborative training of bachelors in cybersecurity in an educational and digital environment 
should be based on the principles of social contact. It was found out that the main principles of collaborative learning in mobile applications for bachelors in cybersecurity in the educational-digital environment included the systematic establishment of social contacts during the training of bachelors in cybersecurity, development of communication, building relationships between bachelors in cybersecurity in educational digital environment on democracy and autonomy, changing the role of participants in the educational process in time depending on the nature and nature of the problem and psychological comfort.

Key words collaborative training, readiness for professional activity, bachelor in cybersecurity, educational and digital environment.

\title{
удк 378.147
}

\author{
Ліліана Хімчук \\ ДВНЗ «Прикарпатський \\ національний університет \\ імені Василя Стефаника» \\ ORCID ID 0000-0002-9243-3131
}

DOI 10.24139/2312-5993/2020.05-06/149-160

\section{БАЗОВІ КОМПЕТЕНТНОСТІ МАЙБУТНІХ УЧИТЕЛІВ ПОЧАТКОВОЇ ШКОЛИ ЯК ПЕДАГОГІЧНА ПРОБЛЕМА СУЧАСНОСТІ}

У статті здійснено теоретичний аналіз категорії базових компетентностей майбутніх учителів початкової школи в сучасних науково-педагогічних дослідженнях. Узагальнено сучасний стан розробленості проблеми в науково-педагогічних джерелах; висвітлено сутність понять «компетенція», «компетентність», «компетентнісний підхід», «базові компетентності майбутніх учителів початкової школи», «ознаки срормованості базових компетентностей». Проаналізовано компетентності на основі освітньо-професійної програми першого (бакалаврського) рівня вищої освіти галузі знань 01 Освіта/Педагогіка зі спечіальності 013 «Початкова освіта» на педагогічному факультеті ДВНз «Прикарпатський національний університет імені Василя Стефраника».

Ключові слова: компетентність, компетентнісний підхід, майбутній учитель початкової школи, базові компетентності, дидактичні принципи.

Постановка проблеми. Актуальність удосконалення професійної підготовки майбутніх учителів зумовлена вимогами сучасного суспільства до індивідуальних, особистісних та професійно-діяльнісних якостей учителя, яких він набуває в період навчання у вищій школі. Суперечність між суспільними потребами й наявним рівнем якості надання освітніх послуг спонукає до переосмислення ролі викладача й майбутнього вчителя та потребує нових підходів до організації їх діяльності на основі партнерства. Особливого значення в даному контексті набуває формування базових компетентностей майбутніх педагогів. Важливо 